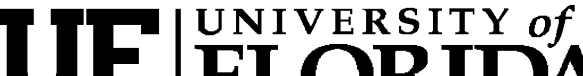 FLORIDA \\ IFAS Extension
}

\section{Smart Irrigation Controllers: Operation of Evapotranspiration-Based Controllers ${ }^{1}$}

\author{
Michael D. Dukes, Mary L. Shedd, and Stacia L. Davis ${ }^{2}$
}

This article is part of a series on smart irrigation

controllers. The rest of the series can be found at

http://edis.ifas.ufl.edu/

TOPIC_SERIES_Smart_Irrigation_Controllers.

\section{Introduction}

Florida has sandy soils in many areas of the state resulting in poor water retention to meet plant water needs. During dry periods, there may not be enough rainfall to maintain acceptable landscape quality. Also, rainy periods have infrequent, high intensity rain events causing only a small portion of water to infiltrate and remain in the root zone while the rest is lost to deep percolation and runoff. Drought conditions can occur in as little as a few days without rain. Previous research has shown that homeowners using in-ground, automatic irrigation systems, typical in Florida, apply $47 \%$ more water for landscape irrigation than homeowners without automatic irrigation systems. This over-irrigation is largely due to a "set it and forget it" mentality despite seasonal fluctuations in plant water needs (Mayer et al., 1999).

"Smart Irrigation Control" technologies for irrigation have been developed to apply irrigation to the landscape based on plant water needs while conserving increasingly limited water resources. One type of technology is an evapotranspiration-based irrigation controller, or ET controller. General information on ET controllers and other smart irrigation technologies can be found in What Makes an Irrigation Controller Smart http://edis.ifas.ufl.edu/AE442, and these technologies in energy efficient housing are described in Energy Efficient Homes: The Irrigation System http://edis.ifas.ufl.edu/FY1043.

This publication will present the operational techniques of several commercially available ET controllers that are being studied at the University of Florida.

\section{Irrigation Scheduling}

Irrigation scheduling is detailed in Basic Irrigation Scheduling in Florida http://edis.ifas.ufl.eduAE111; however, this section will briefly review basic irrigation scheduling concepts.

The water requirement of plants can be determined from a balance of water inputs and

1. This document is AE446, one of a series of the Agricultural and Biological Engineering Department, Florida Cooperative Extension Service, Institute of Food and Agricultural Sciences, University of Florida. Original publication date February 2009. Visit the EDIS Web Site at http://edis.ifas.ufl.edu.

2. Michael D. Dukes, associate professor; Mary L. Shedd, graduate student; Stacia L. Davis, graduate student; Department of Agricultural and Biological Engineering; Florida Cooperative Extension Service, Institute of Food and Agricultural Sciences, University of Florida, Gainesville, FL 32611.

The Institute of Food and Agricultural Sciences (IFAS) is an Equal Opportunity Institution authorized to provide research, educational information and other services only to individuals and institutions that function with non-discrimination with respect to race, creed, color, religion, age, disability, sex, sexual orientation, marital status, national origin, political opinions or affiliations. U.S. Department of Agriculture, Cooperative Extension Service, University of Florida, IFAS, Florida A. \& M. University Cooperative Extension Program, and Boards of County Commissioners Cooperating. Millie Ferrer, Interim Dean 
outputs to the root zone and is called a soil water balance (Figure 1). Rainfall and irrigation enter the root zone as inputs. A shallow water table could also provide water for plant needs through capillary action. Water exits the soil and plant system from runoff, deep percolation, evaporation, and transpiration; these are considered outputs from the soil water balance. Evaporation is the loss of water to the atmosphere from the soil surface and transpiration is the loss of water from respiration of the plants (Allen et al., 1998). When calculating the soil water balance, evaporation and transpiration are combined into one term called evapotranspiration (ET).

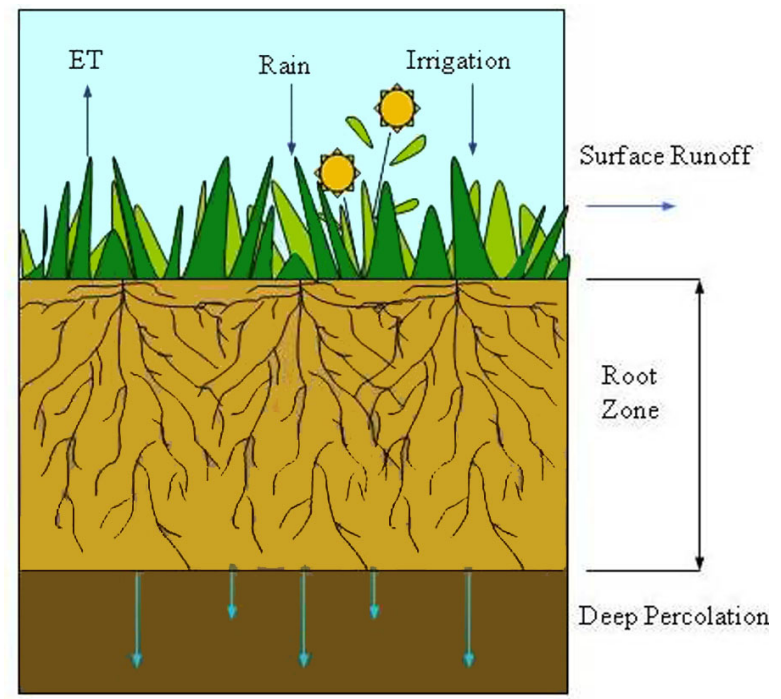

Fig. 1. Water-based inputs and outputs occur in the root zone of a plant assuming well drained conditions without a shallow water table. Credits: Mary L. Shedd

$$
\begin{aligned}
\Delta \mathrm{S}=\mathrm{R}-\mathbf{E} \mathbf{T}_{\mathrm{C}} & +\mathbf{I}-\mathbf{D}-\mathbf{R O} \\
\Delta \mathrm{S} & =\text { Change in soil water storage (in) } \\
\mathbf{R} & =\text { Rainfall (in) } \\
\mathbf{E} \mathbf{T}_{\mathrm{C}} & =\text { Crop evapotranspiration (in) } \\
\mathbf{I} & =\text { Net inigation }(\text { in) } \\
\mathbf{D} & =\text { Deep percolation }(\text { in) } \\
\mathbf{R O} & =\text { Surface run off }(\text { in) }
\end{aligned}
$$

Equation 1. This equation is used to balance the change in soil water storage in the root zone of a plant, also termed the soil water balance equation.

Equation 1 is used for calculating the change in soil water in the root zone (Irrigation Association [IA], 2005). Generally, on sandy soils common in Florida, unless there is excessive compaction or other properties that decrease infiltration of water, it can be assumed that there is negligible surface runoff. Also, irrigation is scheduled so that, ideally, there are negligible losses. Deep percolation is minimized by irrigation events that do not exceed the soil water holding capacity while surface runoff is minimized by using irrigation events just long enough to infiltrate the soil but not runoff (i.e. cycle/soak). The change in storage is typically very small in Florida's sandy soils between necessary irrigation events. These assumptions reduce equation 1 to an equation used to calculate the irrigation depth required:

$$
\begin{aligned}
\mathbf{I}=\mathbf{E T}_{\mathbf{C}}-\mathbf{R}_{\mathbf{E}} & \\
\mathbf{I} & =\text { Net inrigation (in) } \\
\mathbf{E} \mathbf{T}_{\mathbf{C}} & =\text { Crop evapotranspiration (in) } \\
\mathbf{R}_{\mathbf{E}} & =\text { Effective rainfall (in) }
\end{aligned}
$$

Equation 2. This formula is a simplified version of Equation 1 used to calculate net irrigation depth required by assuming negligible drainage, runoff, and change in storage.

Equation 2: This formula is a simplified version of Equation 1 used to calculate net irrigation depth required by assuming negligible drainage, runoff, and change in storage.

Effective rainfall refers to the amount of rainfall that is stored in the root zone (IA, 2005). The ability of the soil to retain water is the soil water holding capacity (IA, 2005). Rainfall that is greater than the soil water holding capacity of the root zone is assumed to drain or run off and is no longer useful to the plant. So how much water can your soil hold?

\section{Calculating Soil Water Content}

The root zone of a plant is the depth of soil from the surface that can be used by the plants to obtain water for physiological processes. The amount of water that can be stored in the root zone is a function of the type of soil texture. Soil texture is discussed in detail in Soil Texture http://edis.ifas.ufl.edu/SS169. The permanent wilting point (PWP) of the soil is defined as the depth or percentage of water in the root zone causing plants to wilt permanently without recovery (IA, 2005; Figure 2). Alternately, field capacity (FC) is defined as the water level when the rate of downward movement in the root zone due to gravity has substantially decreased after saturation (IA, 2005). Theoretically, irrigation should be applied before reaching PWP and filled to FC. Both PWP and 
FC vary with soil texture where the more sandy a soil the less water that can be stored and the more clayey a soil, the more water that can be stored. Water holding capacity as it relates to soil texture is discussed in Soil Plant Water Relationships http://edis.ifas.ufl.edu/AE021.
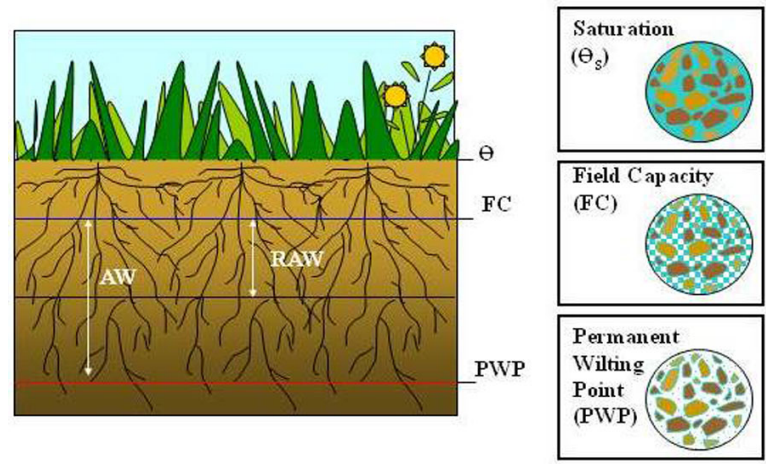

Fig. 2. Diagram of water content in the root zone including: saturation where all soil pore space is filled with water, field capacity is the water remaining in soil pores after gravitational drainage has ceased, permanent wilting point is only thin films of water remaining that is not available to plants. Available water (AW) is the total amount of water held by the soil for plant use, and readily available water (RAW) is the amount of water available for plant use before stress. Credits: Mary L. Shedd

Based on the above definitions, the amount of water available for use by the plant falls between FC and PWP and is termed available water, AW (IA, 2005; Equation 3). To prevent plant stress, AW should not be allowed to reach the PWP before irrigation is scheduled; irrigation should be applied when the available water level drops by a percentage known as the maximum allowable depletion, MAD (IA, 2005). Basic Irrigation Scheduling in Florida http://edis.ifas.ufl.eduAE111 gives details on MAD selection but $50 \%$ is often a rule of thumb in absence of more specific information. The amount of water allowed to be used before irrigation is required is called readily available water, RAW (IA, 2005; Equation 4). As time passes, water is lost from the root zone through $\mathrm{ET}_{\mathrm{C}}$. Daily values of $\mathrm{ET}_{\mathrm{C}}$ are added cumulatively, taking into account effective rainfall, until it equals or is greater than RAW. Once the RAW is depleted, irrigation should occur to fill the soil water store to field capacity.

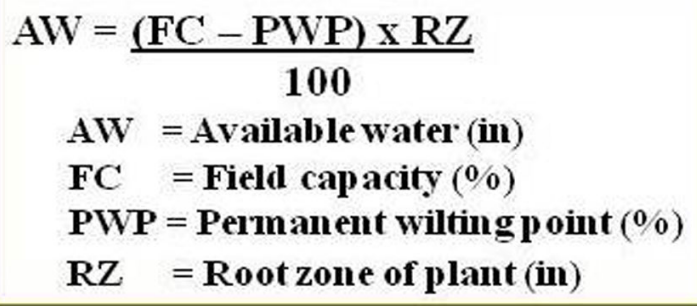

Equation 3. Formulas used to calculate the available water in the root zone.

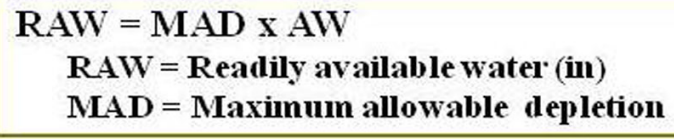

Equation 4. Formula used to calculate the readily available water in a root zone where MAD is a fraction from 0 to 1.

\section{Calculating Evapotranspiration}

Reference evapotranspiration $\left(\mathrm{ET}_{\mathrm{O}}\right)$ is defined as ET from a reference surface using grass at a 0.12 $\mathrm{m}$ height that is adequately-watered, actively growing, completely covering the soil, and with a fixed surface resistance (Allen et al., 2005). The ASCE standardized reference evapotranspiration equation is considered the standard for ET calculations and is commonly used to calculate $\mathrm{ET}_{\mathrm{O}}$ as seen in Equation 5. This equation is used for daily $\mathrm{ET}_{\mathrm{O}}$ calculations and is based on wind speed, temperature, relative humidity, and solar radiation (Figure 3). More information on this method and calculation details can be found at http://www.kimberly.uidaho.edu/water/asceewri/.

$$
\mathrm{ET}_{\mathrm{o}}=\frac{0.408 \Delta\left(\mathrm{R}_{\mathrm{n}}-\mathrm{G}\right)+\gamma \frac{\mathrm{C}_{\mathrm{n}}}{\mathrm{T}+273}\left(\mathrm{e}_{\mathrm{s}}-\mathrm{e}_{\mathrm{a}}\right) \mathbf{u}_{2}}{\Delta+\gamma\left(1+\mathrm{C}_{\mathrm{d}} \mathbf{u}_{2}\right)}
$$

Equation 5. ASCE standardized reference evapotranspiration equation (Allen et al., 2005).

Plant ET $\left(\mathrm{ET}_{\mathrm{C}}\right)$ is defined as ET applicable to a specific plant other than the reference crop. ET $_{C}$ can be calculated for a specific plant material by applying a crop coefficient $\left(\mathrm{K}_{\mathrm{C}}\right)$, using the following equation:

Crop coefficients can be found in a number of references depending on the specific crop, horticultural practices, and geographical location. Sources of crop coefficient data can be found in 


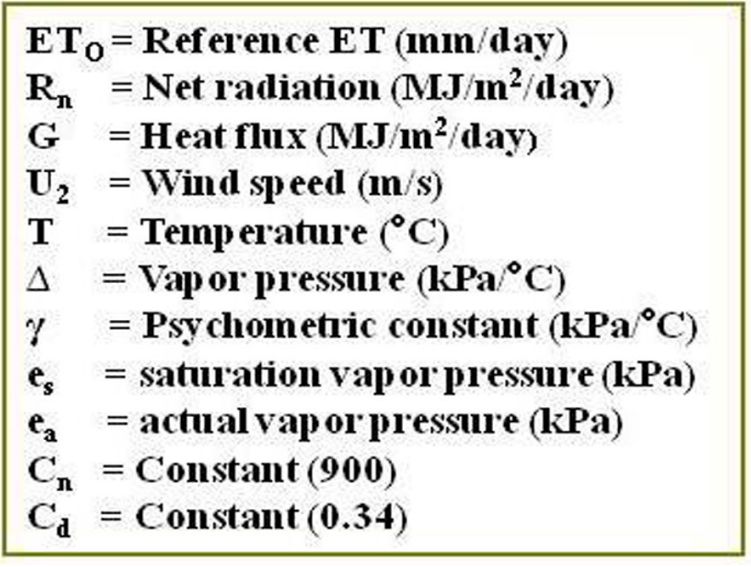

Fig. 3. The variables used in the ASCE standardized reference evapotranspiration equation (Allen et al., 2005). Note that $1 \mathrm{inch} /$ day $=25.4 \mathrm{~mm} /$ day .

$$
\begin{aligned}
& \mathbf{E T}_{\mathrm{C}}=\mathrm{K}_{\mathrm{C}} \times \mathbf{E T}_{\mathrm{O}} \\
& \mathbf{E T}_{\mathrm{C}}=\text { Crop evapotranspiration (in/day) } \\
& \mathbf{K}_{\mathrm{C}}=\text { Crop coefficient }
\end{aligned}
$$

Equation 6. This equation is used to calculate ET loss for a specific crop or plant from reference ET using a crop coefficient.

\section{Basic Irrigation Scheduling in Florida} http://edis.ifas.ufl.eduAE111.

\section{ET Controllers}

ET controllers are irrigation scheduling devices that use the principles of the soil water balance to schedule irrigation amounts and timing. The basic operation of ET controllers is described in What Makes an Irrigation Controller Smart http://edis.ifas.ufl.edu/AE442.

\section{Signal-Based Controllers}

These controllers utilize wired (phone) or wireless (cellular or paging) communication to receive $\mathrm{ET}_{\mathrm{O}}$ data. Weather information is gathered from publicly available or dedicated weather stations near the controller location. Some manufacturers gather the climatic information from the weather stations, calculate a daily value for $\mathrm{ET}_{\mathrm{O}}$, and then broadcast the value directly to the controller each day. Other manufacturers may broadcast weather data from weather stations and the controller then calculates $\mathrm{ET}_{\mathrm{O}}$. $\mathrm{ET}_{\mathrm{C}}$ is calculated from the $\mathrm{ET}_{\mathrm{O}}$ and crop coefficients depending on the plant type selected. The advantage of these controllers is that they adjust in response to actual weather conditions. However, the disadvantage to this approach is that the weather conditions at the weather station data source may not be representative of conditions at the controller location. In particular, Florida site-specific rainfall is very important since rainfall can satisfy much of the plant water requirement. An adequate signal is also important for ensuring accurate soil water balance calculations. Some ET controllers utilize historical data until the signal to the controller is regained; others use the last broadcasted $\mathrm{ET}_{\mathrm{O}}$ value for each day the controller is not in communication. Signal-based controllers generally have the option of adding an external antenna if the built in antenna is insufficient. Three examples of signal-based ET controllers available being studied in Florida are shown in Figure 4.

\section{Standalone Controllers}

These controllers utilize sensors installed on-site to measure weather conditions and then calculate real-time $\mathrm{ET}_{\mathrm{O}}$ based on the data collected. The sensors collect readings at intervals anywhere from every second to every fifteen minutes and then a daily $\mathrm{ET}_{\mathrm{O}}$ is calculated from those values. On-site sensors could include: temperature, solar radiation, or even a full weather station (Riley, 2005). However, installing weather stations at every home is not practical or economically feasible; therefore, simplified ET estimation methods are typically used. For example, the Weathermatic Smartline controller (Figure 5) uses Hargreaves equation instead of the ASCE standardized ET ${ }_{O}$ equation. Hargreaves equation is temperature dependent allowing the sensor to measure only temperature (Jensen et al., 1990). The advantage of this approach is that ET is measured on-site and signal fees are not required. The disadvantage is that simplified methods are not accurate across a wide range of climate conditions (Jensen et al., 1990).

\section{Add-on ET Controllers}

Some ET controllers, such as the Rain Bird ET Manager, are add-on devices to automatic timers and are not equipped with the ability to calculate runtimes. Instead, they use the soil water balance to determine if an irrigation event will occur. The Rain Bird ET Manager has a software program to help 
develop an appropriate irrigation schedule based on site-specific conditions. The schedule is input into the timer and the depth of water per irrigation event calculated by the software is input into the ET Manager. The ET Manager uses the depth input, combined with rainfall and daily ET, to decide when to bypass irrigation events.

\section{Conclusion}

Detailed programming recommendations for several controllers in Florida conditions can be found in Programming Guidelines for Evapotranspiration-Based Irrigation Controllers http://edis.ifas.ufl.edu/AE445.

Note that the University of Florida does not endorse any particular brand but that the information contained here is for illustrative purposes only.

\section{References}

Allen, R.G., L.S. Pereira, D. Raes, and M. Smith. 1998. Crop evapotranspiration - Guidelines for computing crop water requirements. FAO Irrigation and drainage paper 56. Available at: http://www.fao.org/docrep/X0490E/x0490e00.htm. Accessed January 12, 2007.

Allen, R.G., I.A. Walter, R. Elliot, T. Howell, D. Itenfisu, and M. Jensen (eds). 2005. The ASCE Standardized Reference Evapotranspiration Equation. American Society of Civil Engineers Environmental and Water Resource Institute (ASCE-EWRI). 59 pp.

Irrigation Association [IA]. 2005. Landscape Irrigation Scheduling and Water Management. Available at: http://www.irrigation.org/gov/pdf/

IA_LISWM_MARCH_2005.pdf. Accessed January 12, 2007.

Jenson, M.E., R.D. Burman, and R.G. Allen. 1990. Evapotranspiration and Irrigation Water Requirements. ASCE Manuals and Reports on Engineering Practices No. 70. American Society of Civil Engineers. New York, New York.

Mayer, P. W., W. B. DeOreo, E. M. Opitz, J. C. Kiefer, W. Y. Davis, B. Dziegielewski, and J. O. Nelson. 1999. Residential End Uses of Water.
AWWA Research Foundation and American Water Works Association. Denver, Colorado.

Riley, M. (2005). The cutting edge of residential smart irrigation technology. California Landscaping. July/August pp 19-26. 